\title{
Study on Economic Development Potential for Countries along the "Chongqing-Xinjiang-Europe" Railway Route
}

\author{
Huang Sen ${ }^{1 \mathrm{a}}$, GUO Xiao-ming ${ }^{1 \mathrm{~b}}$, Pan Lin-wei ${ }^{2 \mathrm{c} *}$
}

1.Research Center for International Business and Economy, Sichuan International Studies Univers ity, Chongqing,China;

2. School of Economic and Management, Chongqing Jiaotong University, Chongqing,China

amikerwashine@163.com, balicegxm@sina.com, c*360618606@qq.com

Keywords: "Chongqing-Xinjiang-Europe” Railway, Chongqing, Economic Development Potenti al Value, Economic efficiency

\begin{abstract}
As the only inland city located on the node of "One Belt One Road" and "the Y angtze River Economic Belt", Chongqing is positioned as a strategic pivot city in the weste rn conference due to significant geographical advantage. Against this background, in order $t$ o further promote the internationalization of Chongqing, this paper analyzes on the potential and actual economic development of five countries along the "Chongqing-Xinjiang-Europe" $r$ ailway with SE-DEA model in year 2014. It is concluded that Germany ranks first among $t$ he five countries for both the potential and actual economic values. And Russia ranks the $\mathrm{s}$ econd for current economic comprehensive performance, but its economic development poten tial is not encouraging, presenting a trend of diminishing returns to scale. Among the rest $t$ hree countries, for economic development potential, the Republic of Kazakhstan ranks first, followed by Poland and the Republic of Belarus.
\end{abstract}

\section{Introduction}

"Chongqing-Xinjiang-Europe" railway is the transport channel starting from Chongqing, through Kazakhstan, Russia, Belarus, Poland and arriving in Duisburg in Germany. This railway transport channel (total length of 11179 kilometers) is jointly established by the six national railways and customs offices along the way. How can Chongqing improve its international level to promote sustainable economic development through making full use of the "Chongqing-Xinjiang-Europe" railway? It is very necessary to accurately judge the economic strength and development potential of the countries along the route. How is the national economic development level for each country along the international section of "Chongqing-Xinjiang-Europe” railway? Which international cooperation model should Chongqing choose in the process of internationalization? All questions need to be answered. Therefore, this paper, adopting the SE-DEA model, will analyze on the absolute economic value and potential economic value of the five countries along "Chongqing-Xinjiang-Europe" railway, providing discussion on how Chongqing should use the " Chongqing-Xinjiang-Europe " channel to accelerate the international development and other related issues.

\section{Model Principle and Index System}

\subsection{SE-DEA Models}

Data Envelopment Analysis (DEA) is a linear programming method proposed by Charnes, Cooper and Rhodes (1978) based on the measurement of production efficiency (Farrell 1957). In order to better compare the economic development potential of the 5 countries along "Chongqing-Xinjiang- Europe", this paper will use the SE-DEA model among many existing DEA models. The specific expression of the model is: 


$$
\mathrm{s.t} \quad\left(\begin{array}{l}
\sum_{\substack{\mathrm{j}=1 \\
j \neq \mathrm{j}_{0}}}^{\mathrm{min} \theta} \lambda_{\mathrm{j}} \mathrm{x}_{\mathrm{j}}+\mathrm{s}^{-}=\theta \mathrm{x}_{0} \\
\sum_{\substack{\mathrm{j}=1 \\
j \neq \mathrm{j}_{\mathrm{o}}}}^{\mathrm{n}} \lambda_{\mathrm{j}} \mathrm{y}_{\mathrm{j}}-\mathrm{s}^{+}=\mathrm{y}_{0} \\
\lambda_{\mathrm{j}}, \mathrm{s}^{-}, \mathrm{s}^{+} \geq 0 \\
\mathrm{j}=1,2, \cdots, \mathrm{n}
\end{array}\right.
$$

In the formula (1), $\theta$ is the relative comprehensive efficiency of each decision making unit(DUM), which reflects the rational degree of resource allocation of the $j$ DUM. $\lambda_{j}$ represents the linear combination weight of several DUMs. $s_{i}^{-}, s_{i}^{+}$is slack variable, non-zero $s^{-} i, s_{i}^{+}$represents the redundancy of input and the deficiency of output respectively. SE-DEA model can effectively distinguish the efficiency difference between the effective DUMs, and can effectively sort the DUMs.

\subsection{Index System}

Based on the characteristics of economic development and the availability of data along "Chongqing-Xinjiang-Europe" railway, this paper takes human capital investment, fixed assets investment, import and export, research and development(R\&D) investment as input variables, and takes Gross Domestic Product (GDP) as the output variable. The samples are five countries: Kazakhstan, Russia, Belarus, Poland and Germany. Sample time is year 2014. Is has to be explained that in order to eliminate the effect of inflation, all indicators are converted to constant 2010 dollars. Since data of R\&D investment in year 2014 is missed, so we use corresponding data of year 2013 instead. All the data in this paper are from the World Bank statistics database and the corresponding statistical yearbook of each country. The specific is shown in table 1:

Table 1 input-output index system

\begin{tabular}{ccc}
\hline system & Variable & measurement unit \\
\hline \multirow{3}{*}{ input } & fixed assets investment & Million dollars \\
& human capital investment & Thousand Person \\
output & Import and export & Million dollars \\
R\&D investment & Million dollar \\
\hline
\end{tabular}

The five countries' economic development data is presented in Table 2, which shows that for the overall national development strength, Germany is undoubtedly the first, and the rest are Russia, Poland, Kazakhstan and Belarus listing according to their ranking. In terms of the core competitiveness of economic development, Germany behaves the best, with a small amount of human capital investment and a large amount of fixed capital investment, creating a much higher GDP than Russia. The reason of this excellent economic performance, in addition to its reasonable allocation of investment, can't be separated from the higher R\&D investment. As table2 shows, Germany's spending on R\&D is 8.29 times higher than Russia which ranks the second.

Table 2 Data of 5 countries along “Chongqing-Xinjiang-Europe”(2014)

\begin{tabular}{cccccc}
\hline Country & GDP & $\begin{array}{c}\text { human capital } \\
\text { investment }\end{array}$ & $\begin{array}{c}\text { fixed assets } \\
\text { investment }\end{array}$ & $\begin{array}{c}\text { Import and } \\
\text { export }\end{array}$ & $\begin{array}{c}\text { R\&D } \\
\text { investment }\end{array}$ \\
\hline Kazakhstan & $182,836.75$ & $9,284.81$ & $44,710.72$ & 115,626 & 147.88 \\
Russia & $1,678,708.85$ & $76,754.17$ & $374,786.10$ & $812,998.7$ & $11,126.85$ \\
Belarus & $60,960.47$ & $4,489.04$ & $22,777.29$ & $69,848.51$ & 326.16 \\
Poland & $534,558.02$ & $18,280.16$ & $112,849.26$ & $500,453.2$ & $3,739.70$ \\
Germany & $3,624,386.27$ & $42,213.45$ & $723,614.15$ & $3,070,405$ & $92,330.81$ \\
\hline
\end{tabular}

\section{Potential Measurement}

With the SE-DEA model, this paper measures the economic development potential of 5 countries in 2014, and the specific data is shown in table 3. In 2014, Belarus's economic development 
potential is less than 1 , while the other four countries are higher than 1 . In the four countries whose economic potential is more than 1, Kazakhstan has the highest economic potential, and Germany, Poland and Russia are following from high to low.

Table 3 The economic development potential 、Scale compensation and input slacks

\begin{tabular}{ccccccc}
\hline Country & $\begin{array}{c}\text { Economic } \\
\text { potential }\end{array}$ & $\begin{array}{c}\text { Scale } \\
\text { compensation }\end{array}$ & $\begin{array}{c}\text { human capital } \\
\text { investment }\end{array}$ & $\begin{array}{c}\text { fixed assets } \\
\text { investment }\end{array}$ & $\begin{array}{c}\text { Import and } \\
\text { export }\end{array}$ & $\begin{array}{c}\text { R\&D } \\
\text { investment }\end{array}$ \\
\hline Kazakhstan & 6.6151 & Decreasing & + & - & - & - \\
Russia & 1.3058 & Decreasing & - & - & - & + \\
Belarus & $\mathbf{0 . 6 2 0 9}$ & Increasing & + & + & + & + \\
Poland & 1.1494 & Decreasing & - & - & + & - \\
Germany & 2.9361 & Decreasing & - & - & - & + \\
\hline
\end{tabular}

How could the 5 countries improve their potential for economic development? As shown in table 3, Kazakhstan's primary consideration is to increase labor input, and Russia's primary consideration is to increase R\&D investment. The four types of inputs of Belarus need to be increased, and Poland 's primary task is to increase import and export. Germany also needs to increase its R\&D investment. From the perspective of scale compensation, Belarus presents the increasing trend and other countries presents the decreasing. This conclusion shows that Belarus will have obvious advantage in enhancing its economic development potential by changing the allocation of resources.

Table 4 Model Selection of Chongqing International Cooperation

\begin{tabular}{ccccc}
\hline Country & Labor exchange & Transnational investment & international trade & Technical cooperation \\
\hline Kazakhstan & $\sqrt{ }$ & - & - & - \\
Russia & - & - & - & $\sqrt{ }$ \\
Belarus & $\sqrt{ }$ & $\sqrt{ }$ & $\sqrt{ }$ & $\sqrt{ }$ \\
Poland & - & - & - & - \\
Germany & - & - & $\sqrt{ }$ \\
\hline
\end{tabular}

Based on the above analysis, we can conclude that, in order to improve their economic potential and ensure the sustained and effective economic growth, the five countries along the route of

"Chongqing-Xinjiang-Europe" railway need to allocate different inputs. Chongqing should cooperate with these countries on different focuses to make use of their strength and avoid their short comings. Table 4 suggests the best international cooperation models for each country. With Kazakhstan Chongqing should focus on labor exchange, and for Russia and Germany, Chongqing should concentrate on technical cooperation. As to Poland Chongqing can mainly cooperate in international trade and for Belarus, Chongqing can build up the comprehensive cooperation.

\section{Conclusion}

Based on the SE-DEA method, this paper analyzes the economic development trend of the five countries along the "Chongqing-Xinjiang-Europe" railway, and points out that Chongqing should adopt diversified international cooperation models with them. The specific conclusions are:

(1) Compared with the Europe traditional countries such as Germany and Russia, the overall technology level of Chongqing is in disadvantage, but some professional areas still have competitive advantages (e.g single-track-traffic technology). Chongqing should take full advantage of the existing leading industries, and rely on two paths("technology $\rightarrow$ capital $\rightarrow$ technology" or "technology $\rightarrow$ technology") to absorb advantageous technological elements needed.

(2) Compared with some Central Asian and Eastern European countries such as Kazakhstan, Poland, Belarus, Chongqing has a clear comparative advantage, while these countries also have good economic development potential, thus the pace of bilateral cooperation can be accelerated, especially in aspects of human resources and capital cooperation. The rational use of foreign exchange reserves will help these countries to improve the infrastructure and release excess capacity of Chongqing , making room for strategic development of emerging industries. At the same time, the rich natural resources of these countries can also ease the over-exploitation of similar resources in Chongqing (such as Kazakhstan's oil and natural gas) and create a favorable environment for the development of strategic emerging industries. 
Sponsored by: Annual scientific research project of Chongqing Social Science Planning (201 5QNJJ11); National Social Science Fund of China (14XJL004); Annual scientific research project of Sichuan International Studies University (SISU201526) \& (SISU201531)

\section{References}

[1] James C.Davids and J.Vernon Henderson. Evidence on the Political Economy of the Urbanization Process[J]. Journal of Urban Economics.2003,(53):98-125.

[2] Markus Brückner. Economic growth, size of the agricultural sector, and urbanization in Africa[J]. Journal of Urban Economics . 2012 , (1): 26-36.

[3] Joshua Drucker,Edward Feser. Regional industrial structure and agglomeration economies: An analysis of productivity in three manufacturing industries[J]. Regional Science and Urban Economics,2012,(1-2): 1-14.

[4] Gregg Huff,Luis Angeles. Globalization, industrialization and urbanization in Pre-World War II Southeast Asia[J]. Exploration in Economic History, 2011,(1): 20-36.

[5] Research on the Economic Growth Potential of Jiangxi Province [J]. Finance and Economy, 2003,05: 32-37. 